\title{
Systemic Radiation Therapy
}

National Cancer Institute

\section{Source}

National Cancer Institute. Systemic Radiation Therapy. NCI Thesaurus. Code C92991.

Radiation therapy in which radioactive drugs are administered orally or through an

injection then circulate through the blood and collect in tumor sites where they kill cancer cells. 